\title{
SINDROM RUBELLA KONGENITAL
}

\author{
Julia Fitriany $^{1}$, Yulia Husna ${ }^{2}$ \\ ${ }^{1}$ Bagian Ilmu Kesehatan Anak, Universitas Malikussaleh, Uteunkot, Lhokseumawe \\ ${ }^{2}$ Mahasiswa Program Studi Pendidikan Dokter, Universitas Malikussaleh, Uteunkot, Lhokseumawe \\ *Corresponding Author : yuliahusna48@gmail.com
}

\begin{abstract}
Abstrak
Congenital Rubella Syndrome (CRS) adalah suatu kumpulan gejala penyakit terdiri dari katarak, penyakit jantung bawaan, gangguan pendengaran, dan keterlambatan perkembangan. Sindrom rubella kongenital disebabkan infeksi virus rubella pada janin selama masa kehamilan akibat ibu tidak mempunyai kekebalan terhadap virus rubella.. Virus rubella ditransmisikan melalui pernapasan yaitu melalui droplet yang dikeluarkan oleh seseorang yang terinfeksi rubella, setelah terkena droplet, virus ini akan mengalami replikasi di nasofaring dan di daerah kelenjar getah bening. Viremia terjadi antara hari ke-5 sampai hari ke-7 setelah terpajan virus rubella. Infeksi rubella menyebabkan kerusakan janin karena proses pembelahan terhambat. Diagnosis dari CRS bisa ditegakkan melalui anamnesis, pemeriksaan fisik dan pemeriksaan pebunjang. Pemeriksaan laboratorium untuk menunjang diagnosis CRS antara lain: isolasi virus, pemeriksaan serologik (ELISA) dan pemeriksaan terhadap RNA virus rubella. Terapi untuk CRS sendiri hanya bersifat suportif untuk defekdefek yang dialami. Penting untuk mencegah CRS adalah dengan vaksin MMR sebelum hami. Prognosis untuk CRS lebih buruk dibandingkan dengan rubella postnatal karena disertai kerusakan organ multiple yang berat.
\end{abstract}

Kata Kunci: CRS, Rubella, MMR

\section{Congenital Rubella Syndrome (CRS)}

\begin{abstract}
Congenital Rubella Syndrome (CRS) is a collection of symptoms of disease consisting of cataracts, congenital heart disease, hearing loss, and developmental delays. Congenital rubella syndrome is caused by infections of the rubella virus in the fetus during pregnancy because the mother has no immunity to the rubella virus. The rubella virus is transmitted through the breath, the droplet released by someone infected with rubella, after being exposed to droplet, the virus will undergo replication in the nasopharynx and in the lymph node area. Viremia occurs between day 5 to day 7 after exposure to the rubella virus. Rubella infections cause fetal damage because the division process is inhibited. Diagnosis of CRS can be established through anamnesis, physical examination and inspection pebunjang. Laboratory tests to support CRS diagnosis include: virus isolation, serologic examination (ELISA) and examination of RNA virus rubella. Therapy for CRS alone is only supportive for the defects experienced. It is important to prevent CRS is with MMR vaccine before hami. The prognosis for CRS is worse than postnatal rubella because it is accompanied by severe multiple organ damage.
\end{abstract}

Keywords: CRS, Rubella, MMR

Jurnal Averrous Vol.4 No.1 2018 


\section{Pendahuluan}

Rubella dikenal masyarakat luas sebagai campak jerman. Infeksi rubella jika terjadi pada bayi, anak, atau orang dewasa tidak berakibat fatal, tetapi jika terjadi pada ibu hamil dan virus tersebut menginfeksi janin yang sedang dalam kandungan akan berakibat fatal dan dapat menyebabkan Congenital Rubella Syndrome (CRS. ${ }^{1}$

Congenital Rubella Syndrome (CRS) adalah suatu kumpulan gejala penyakit terdiri dari katarak (kekeruhan lensa mata), penyakit jantung bawaan, gangguan pendengaran, dan keterlambatan perkembangan, termasuk keterlambatan bicara dan disabilitas intelektual. Sindrom rubella kongenital disebabkan infeksi virus rubella pada janin selama masa kehamilan akibat ibu tidak mempunyai kekebalan terhadap virus rubella. Seorang anak dapat menunjukkan satu atau lebih gejala CRS dengan gejala tersering adalah gangguan pendengaran. ${ }^{1}$ Jika infeksi virus rubella terjadi pada kehamilan, khususnya trimester pertama sering menyebabkan Congenital Rubella Syndrome. CRS mengakibatkan terjadinya abortus, bayi lahir mati, prematur dan cacat apabila bayi tetap hidup. Nama lain CRS ialah Fetal Rubella Syndrome. Cacat bawaan (Congenital defect) yang paling sering dijumpai ialah tuli sensoneural, kerusakan mata seperti katarak, gangguan kardiovaskular, dan retardasi mental. ${ }^{2}$

Selama pandemi rubella global 1962-1965, diperkirakan 12,5 juta kasus rubella terjadi di Amerika Serikat, mengakibatkan 2.000 kasus ensefalitis, 11.250 aborsi spontan, 2.100 kematian neonatal, dan 20.000 bayi lahir dengan CRS. Semenjak ada vaksin Rubella jumlah kasus CRS yang dilaporkan di Amerika Serikat menurun secara dramatis menjadi $<2 / 100.000$ kelahiran hidup. Negara berkembang seperti Indonesia tentu patut mempertimbangkan program imunisasi mengingat masalah kesehatan dan kecacatan yang dapat ditimbulkan. ${ }^{1}$

\section{TINJAUAN PUSTAKA}

\section{Definisi}

Congenital Rubella Syndrome (CRS) adalah penyakit pada bayi oleh karena infeksi maternal dengan rubella virus selama kehamilan. Ketika infeksi rubella terjadi selama awal kehamilan, konsekuensi serius seperti abortus, IUFD dan cacat lahir yang parah pada bayi dapat terjadi. Itu risiko infeksi kongenital dan kecacatan paling tinggi selama 12 minggu pertama kehamilan dan menurun setelah minggu ke 12 kehamilan; cacat jarang terjadi setelah infeksi pada minggu ke-20 (atau sesudahnya) kehamilan. ${ }^{3}$ 
Congenital Rubella Syndrome (CRS) merupakan gabungan beberapa keabnormalan fisik yang berkembang di bayi sebagai akibat infeksi virus rubella maternal yang berlanjut dalam fetus. Nama lain CRS ialah Fetal Rubella Syndrome. Cacat kongenital (congenital defect) yang paling sering dijumpai ialah tuli sensoneural, kerusakan mata seperti katarak, gangguan kardiovaskular, dan retardasi mental. ${ }^{3}$

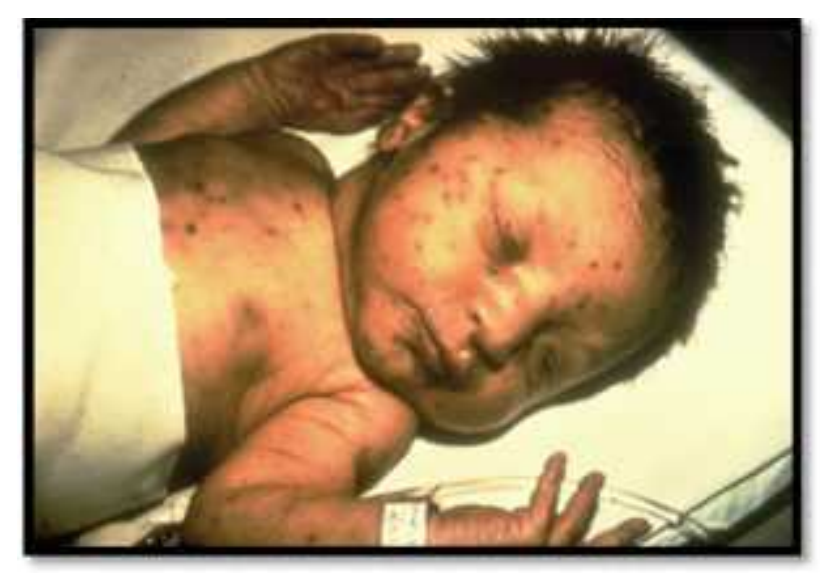

Gambar 1. Bayi dengan rubella

\section{Epidemiologi}

CRS pertama kali dilaporkan pada tahun 1941 oleh Norman Gregg seorang spesialis mata Australia yang menemukan katarak kongenital pada 78 bayi yang ibunya mengalami infeksi rubella di awal kehamilannya. Berdasarkan data dari WHO sekitar 236.000 kasus CRS terjadi setiap tahun di Negara berkembang dan meningkat 10 kali lipat saat terjadi epidemik. ${ }^{3}$ Selama pandemi rubella global 1962-1965, diperkirakan 12,5 juta kasus rubella terjadi di Amerika Serikat, mengakibatkan 2.000 kasus ensefalitis, 11.250 aborsi spontan, 2.100 kematian neonatal, dan 20.000 bayi lahir dengan CRS. Rubela di negara maju saat ini tidak lagi merupakan masalah kesehatan dengan luasnya cakupan imunisasi. Negara berkembang seperti Indonesia tentu patut mempertimbangkan program imunisasi mengingat masalah kesehatan dan kecacatan yang dapat ditimbulkan. ${ }^{1}$ Pada tahun 1969, vaksin rubella hidup dilisensikan di Amerika Serikat. Tujuan program vaksinasi adalah eliminasi rubella dan terus menjadi pencegahan infeksi rubella kongenital, termasuk CRS. Pada tahun 2004, panel independen yang diakui secara internasional ahli dalam kesehatan masyarakat, penyakit menular, dan imunisasi meninjau data yang tersedia tentang epidemiologi rubella dan dengan suara bulat setuju bahwa eliminasi rubella (yaitu, tidak adanya transmisi endemik sepanjang tahun) telah dicapai di Amerika Serikat. Selama 2005-2015, jumlah kasus CRS yang dilaporkan di Amerika Serikat menurun secara dramatis menjadi <2/100.000 kelahiran hidup, 1,7 di Israel, 1,5 di Singapura dan 0,5 di Malaysia. Untuk di Indonesia, studi tentang kejadian rubella tidak banyak dilakukan. Namun dari studi yang sedikit ini, diperkirakan kejadian 
infeksi rubella cukup tinggi ${ }^{3}$ Data Riskesdas $2011 \pm 400$ kasus sindom rubela kongenital, sedangkan menurut WHO pada tahun 2012 sekitar 5000-10.000 bayi lahir dengan tuli pertahun. $^{3}$

\section{Etiologi CRS}

Etiologi dari CRS adalah virus rubella. Tahun 1941, CRS untuk pertama kalinya dilaporkan oleh Norman Greg (spesialis mata dari Australia). Norman menemukan katarak kongenital pada bayi yang ibunya terinfeksi Rubella di trimester awal kehamilannya. ${ }^{3}$

\section{Struktur Virus Rubella}

Virus rubella diisolasi pertamakali pada tahun 1962 oleh Parkman dan Weller. Rubella merupakan virus RNA yang termasuk dalam genus Rubivirus, famili Togaviridae, dengan jenis antigen tunggal yang tidak dapat bereaksi silang dengan sejumlah grup Togavirus lainnya. Virus rubella memiliki 3 protein struktural utama yaitu 2 glycoprotein envelope, E1 dan E2 dan 1 protein nukleokapsid. Secara morfologi, virus rubella berbentuk bulat (sferis) dengan diameter 50-70 $\mathrm{mm}$ dan memiliki inti (core) nukleoprotein padat, dikelilingi oleh dua lapis lipid yang mengandung glycoprotein E1 dan E2. Virus rubella dapat dihancurkan oleh proteinase, pelarut lemak, formalin, sinar ultraviolet, $\mathrm{PH}$ rendah, panas dan amantadine tetapi relatif rentan terhadap pembekuan, pencairan atau sonikasi. ${ }^{2}$

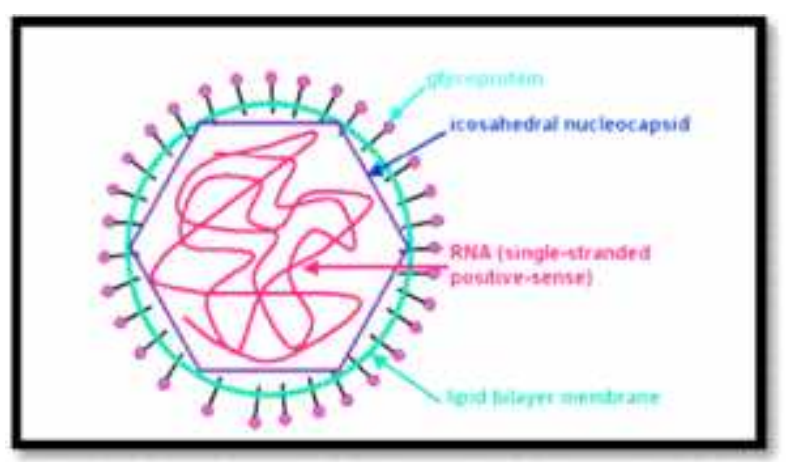

\section{Gambar 2.Virus Rubella}

Virus Rubella terdiri atas dua subunit struktur besar, satu berkaitan dengan envelope virus dan yang lainnya berkaitan dengan nucleoprotein core Virus Rubella terdiri dari lapisan glycoprotein, lemak \& inti dengan RNA. ${ }^{3}$

\section{Patogenesis}

Virus rubella ditransmisikan melalui pernapasan yaitu melalui droplet yang dikeluarkan oleh seseorang yang terinfeksi rubella, setelah terkena droplet, virus ini akan mengalami replikasi di nasofaring dan di daerah kelenjar getah bening. Viremia terjadi antara 
hari ke-5 sampai hari ke-7 setelah terpajan virus rubella. Dalam ruangan tertutup, virus rubella dapat menular ke setiap orang yang berada di ruangan yang sama dengan penderita. Masa inkubasi virus rubella berkisar antara 14-21 hari. Masa penularan 1 minggu sebelum dan 4 hari setelah onset ruam (rash). Pada episode ini, Virus rubella sangat menular. ${ }^{4}$

Ketika infeksi virus rubella terjadi selama awal kehamilan, maka resiko resiko serius lebih sering terjadi yaitu abortus, lahir mati dan sebagainya. Resiko infeksi kongenital dan defek meningkat selama kehamilan 12 minggu pertama dan menurun setelah kehamilan diatas 12 minggu dengan defek jarang terjadi pada kehamilan 20 minggu. ${ }^{7}$ Jika infeksi terjadi pada bulan pertama kehamilan, risiko terkena CRS sebesar 43 persen. Risiko tersebut meningkat menjadi 51 persen jika infeksi terjadi pada 3 bulan pertama kehamilan, Risiko menurun jika infeksi terjadi setelah 3 bulan pertama kehamilan (23 persen). ${ }^{1}$

Infeksi transplasenta janin dalam kandungan terjadi saat viremia berlangsung. Infeksi rubella menyebabkan kerusakan janin karena proses pembelahan terhambat. Dalam sekret faring dan urin bayi dengan CRS, terdapat virus rubella dalam jumlah banyak yang dapat menginfeksi bila bersentuhan langsung. Virus dalam tubuh bayi dengan CRS dapat bertahan hingga beberapa bulan atau kurang dari 1 tahun setelah kelahiran. ${ }^{5}$

Kerusakan janin disebabkan oleh berbagai faktor, misalnya oleh kerusakan sel akibat virus rubella dan akibat pembelahan sel oleh virus. Infeksi plasenta terjadi selama viremia ibu, menyebabkan daerah nekrosis yang tersebar secara fokal di epitel vili korealis dan sel endotel kapiler. Sel ini mengalami deskuamasi ke dalam lumen pembuluh darah, virus rubella kemudian masuk ke dalam sirkulasi janin sebagai emboli sel endotel yang terinfeksi. Hal ini selanjutnya mengakibatkan infeksi dan kerusakan organ janin. Selama kehamilan muda mekanisme pertahanan janin belum matang dan gambaran khas embriopati pada awal kehamilan adalah terjadinya nekrosis seluler tanpa disertai tanda peradangan. ${ }^{6}$

Sel yang terinfeksi virus rubella memiliki umur yang pendek. Organ janin dan bayi yang terinfeksi memiliki jumlah sel yang lebih rendah daripada bayi yang sehat. Virus rubella juga dapat memicu terjadinya kerusakan dengan cara apoptosis. Jika infeksi maternal terjadi setelah trimester pertama kehamilan, frekuensi dan beratnya derajat kerusakan janin menurun drastis. Perbedaan ini terjadi karena janin terlindung oleh perkembangan respon imun janin, baik yang bersifat humoral maupun seluler, dan adanya antibodi maternal yang ditransfer secara pasif. $^{8}$

Pada infeksi rubella maternal, yang biasanya terjadi lima sampai tujuh hari setelah inokulasi pada ibu, virus menyebar ke seluruh plasenta secara hematogen, yang mengarah kepada infeksi bawaan yang potensial pada janin yang sedang berkembang. Pada infeksi 
rubella maternal dengan ruam, frekuensi infeksi kongenital adalah lebih dari $80 \%$ selama 12 minggu pertama kehamilan, sekitar 54\% di 13-14 minggu, dan sekitar 25\% pada akhir trimester kedua. Setiap infeksi rubella maternal yang terjadi setelah 16 minggu kehamilan, tidak ada risiko terjadi sindrom rubella kongenital pada bayi yang baru lahir. ${ }^{10}$

Dari beberapa studi menunjukkan bahwa rute infeksi virus rubella adalah melalui organ sistemik pada janin manusia. Fakta ini telah dikonfirmasi oleh tes imunohistokimia dan deteksi langsung dari RNA virus di beberapa organ. Perubahan histopatologi yang utama diamati dalam hepar. Hepar embrio memiliki peran yang sangat penting dalam proses hematopoiesis selain sumsum tulang. Temuan antigen virus di sel epitel glomerulus dan tubulus proksimal pada ginjal juga menunjukkan ekskresi virus dalam urin. ${ }^{6}$

\section{Manifestasi Klinis}

Rubella merupakan penyakit infeksi diantaranya 20-50\% kasus bersifat asimptomatis. Gejala rubella hampir mirip dengan penyakit lain yang disertai ruam. Gejala klinis untuk mendiagnosis infeksi virus rubella pada orang dewasa atau pada kehamilan adalah: ${ }^{3}$

1. Infeksi bersifat akut yang ditandai oleh adanya ruam makulopapular.

2. Suhu tubuh $>37,2^{0} \mathrm{C}$

3. Artralgia/artrhitis, limfadenopati, konjungtivitis.

CRS yang meliputi 4 defek utama yaitu :

a. Gangguan pendengaran tipe neurosensorik. Timbul bila infeksi terjadi sebelum umur kehamilan 8 minggu. Gejala ini dapat merupakan satu-satunya gejala yang timbul.

b. Gangguan jantung meliputi PDA, VSD dan stenosis pulmonal.

c. Gangguan mata : katarak dan glaukoma. Kelainan ini jarang berdiri sendiri.

d. Retardasi mental dan beberapa kelainan lain antara lain:

- Purpura trombositopeni (Blueberry muffin rash)

- Hepatosplenomegali, meningoensefalitis, pneumonitis, dan lain-lain.

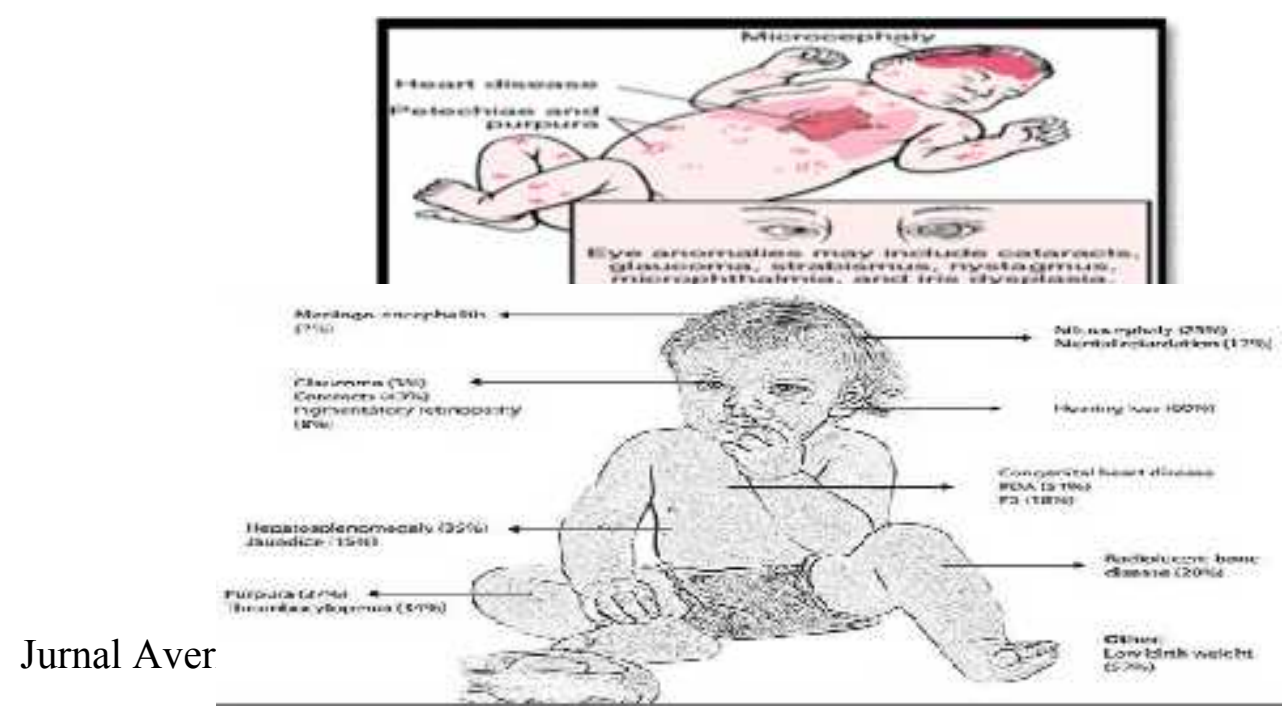




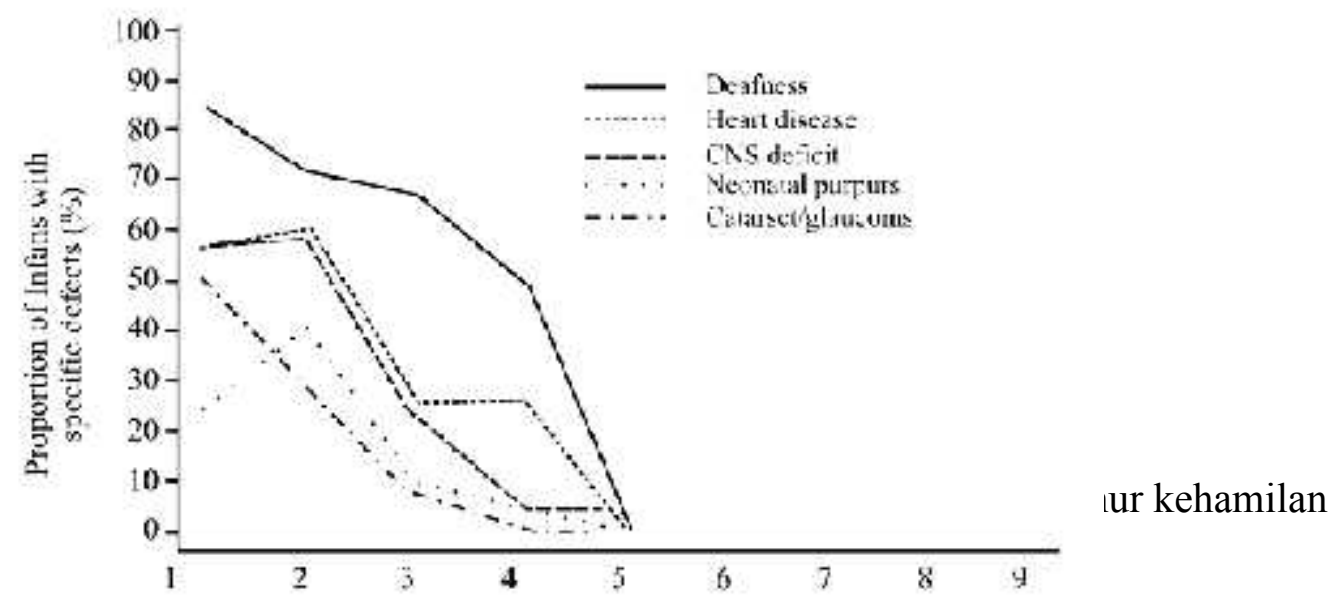

Krite

Gestatioral age with

Risiko infeksi janin beragam berdasarkan waktu terjadinya infeksi maternal. Infeksi terjadi pada 0-12 minggu usia kehamilan, maka terjadi 80-90\% risiko infeksi janin. Infeksi maternal yang terjadi sebelum terjadi kehamilan tidak mempengaruhi janin. Infeksi maternal pada usia kehamilan 15-30 minggu risiko infeksi janin menurun yaitu 30\% atau 10-20\%.

Bayi di diagnosis mengalami CRS apabila mengalami 2 gejala pada kriteria A atau 1 kriteria A dan 1 kriteria B, sebagai berikut: ${ }^{3}$

A. Katarak, glaukoma kongenital, penyakit jantung kongenital (paling sering adalah PDA atau peripheral pulmonary artery stenosis), kehilangan pendengaran, pigmentasi retina.

B. Purpura, splenomegali, jaundice, mikrosefali, retardasi mental, meningoensefalitis dan radiolucent bone disease (tulang tampak gelap pada hasil foto roentgen).

Beberapa kasus hanya mempunyai satu gejala dan kehilangan pendengaran merupakan cacat paling umum yang ditemukan pada bayi dengan CRS. Definisi kehilangan pendengaran menurut WHO adalah batas pendengaran $\geq 26 \mathrm{~dB}$ yang tidak dapat disembuhkan dan bersifat permanen 3

\section{Klasifikasi Kasus}

Berdasarkan kriteria diagnosis klinis dan hasil pemeriksaan laboratorium, kasus CRS dapat digolongkan menjadi 4 kelompok yaitu: ${ }^{3}$

1. Kasus kecurigaan (Suspected case)

Suspected case adalah kasus dengan beberapa gejala klinis tetapi tidak memenuhi kriteria klinis untuk diagnosis CRS tetapi yang memiliki 1 atau lebih banyak temuan berikut:

- Katarak, 
- Glaukoma kongenital,

- Penyakit jantung kongenital (paling sering paten duktus arteriosus atau arteri pulmonalis perifer

- Stenosis),

- Gangguan pendengaran,

- Retinopati pigmen,

- Purpura,

- Hepatosplenomegali,

- Sakit kuning,

- Mikrosefali,

- Keterlambatan pengembangan,

- Meningoencephalitis, atau

- Penyakit tulang radiolusen ${ }^{3}$

2. Kasus berpeluang (Probable case).

Pada kasus ini, hasil pemeriksaan laboratorik tidak sesuai dengan kriteria laboratorium untuk diagnosis CRS, tetapi mempunyai 2 penyulit (komplikasi) yang tersebut pada kriteria A atau satu penyulit pada kriteria A dan satu penyulit pada kriteria B dan tidak ada bukti etiologi. Pada kasus berpeluang (probable case), baik satu atau kedua kelainan yang berhubungan dengan mata (katarak dan glaukoma kongenital), dihitung sebagai penyulit tunggal. Jika dikemudian hari ditemukan/terkenali (identifikasi) keluhan atau tanda yang berhubungan seperti kehilangan pendengaran, kasus ini akan digolongkan ulang.

3. Kasus hanya infeksi (Infection only-case)

Kasus hanya infeksi (Infection only-case) adalah kasus yang diperoleh dari hasil pemeriksaan laboratorik terbukti ada infeksi tetapi tidak disertai tanda dan gejala klinis CRS.

4. Kasus terpastikan (Confirmed case). Dalam kasus ini dijumpai gejala klinis dan didukung oleh hasil pemeriksaan laboratorik yang positif.

\section{Diagnosis}

Anamnesis

Untuk mendiagnosa rubella congenital maka harus ada riwayat terjadi rubella pada ibunya, yang ditandai dengan gejala-gejala di atas. ${ }^{7}$

1. Pemeriksaan fisik

Untuk CRS dapat diidentifikasikan dari pemeriksaan fisik, yaitu dari kepala dapat kita temukan adanya microcephali, pada mata biasanya ditemukan tanda kelainan di bola mota 
berupa adanya katarak dan peningkatan tekanan intra okuler atau biasa disebut glaucoma. Pada telinga terdapat kelainan pendengaran yaitu ketulian yang dapat dideteksi setelah usia masa pertumbuhan. Kemudian pada pemeriksaan jantung dapat ditemukan adanya kelainan berupa patent duktus arteriosus ditandai dengan adanya murmur derajat I-IV. Namun tandatanda diatas tidak patoknomonik untuk diagnosis klinis sering kali sukar dibuat untuk seorang penderita oleh karena tidak ada tanda atau gejala yang patognomik untuk rubella. ${ }^{9}$

\section{Pemeriksaan penunjang}

Pemeriksaan laboratorium dilakukan untuk menunjang diagnosis infeksi virus rubella dan untuk status imunologis. Karena prosedur isolasi virus sangat lama dan mahal serta respon antibodi inang sangat cepat dan spesifik maka pemeriksaan serologis lebih sering dilakukan. Bahan pemeriksaan untuk menentukan adanya infeksi virus rubella dapat diambil dari apusan (swab) tenggorok, darah, urin dan lain-lain. Berikut tabel yang memuat jenis pemeriksaan dan spesimen yang digunakan untuk menentukan infeksi virus rubella.

Tabel 1. Jenis pemeriksaan \& spesimen untuk menentukan virus rubella

\begin{tabular}{|c|c|c|c|}
\hline \multirow[t]{2}{*}{ No } & \multirow{2}{*}{ Jenis Pemeriksaan } & \multicolumn{2}{|c|}{ Jenis Spesimen } \\
\hline & & Fetus/bayi & Ibu \\
\hline 1 & Isolasi Virus & $\begin{array}{l}\text { Sekret hidung, darah, } \\
\text { apusan tenggorok, urin, } \\
\text { cairan serebrospinal }\end{array}$ & $\begin{array}{l}\text { Sekret hidung, darah, } \\
\text { apusan tenggorok, } \\
\text { urin, cairan } \\
\text { serebrospinal. }\end{array}$ \\
\hline 2 & Serologik & $\begin{array}{l}\text { Darah fetus melalui } \\
\text { kordosintesis, } \\
\text { ludah }\end{array}$ & Darah \\
\hline 3 & RNA & $\begin{array}{l}\text { Cairan amnion fetus } \\
\text { melalui amniosintesis, } \\
\text { vili korealis, darah, ludah }\end{array}$ & Darah \\
\hline
\end{tabular}

Secara garis besar, pemeriksaan laboratorik untuk menentukan infeksi virus rubella dibagi menjadi 3 yaitu:

1. Isolasi virus

Virus rubella dapat diisolasi dari sekret hidung, darah, apusan tenggorok, urin, dan cairan serebrospinalis penderita rubella. Virus juga dapat diisolasi dari faring 1 minggu sebelum dan hingga 2 minggu setelah munculnya ruam. Meskipun metode isolasi ini merupakan diagnosis pasti untuk menentukan infeksi rubella, metode ini jarang dilakukan 
karena prosedur pemeriksaan yang rumit. Hal ini menyebabkan metode isolasi virus bukan sebagai metode diagnostik rutin. Untuk isolasi secara primer spesimen klinis, sering menggunakan kultur sel yaitu Vero; African green monkey kidney (AGMK) atau dengan RK-13. Virus rubella dapat ditemui dengan adanya Cytophatic effects (CPE).

2. Pemeriksaan serologi

Pemeriksaan serologis digunakan untuk mendiagnosis infeksi virus rubella kongenital dan pascanatal (sering dikerjakan di anak-anak dan orang dewasa muda) dan untuk menentukan status imunologik terhadap rubella.

Pemeriksaan terhadap wanita hamil yang pernah bersentuhan dengan penderita rubella, memerlukan upaya diagnosis serologis secara tepat dan teliti. Jika penderita memperlihatkan gejala klinis yang semakin memberat, maka harus segera dikerjakan pemeriksaan imunoasai enzim (ELISA) terhadap serum penderita untuk menetukan adanya IgM spesifik-rubella, yang dapat dipastikan dengan memeriksa dengan cara yang sama setelah 5 hari kemudian. Penderita tanpa gejala klinis tetapi terdiagnosis secara serologis merupakan sebuah masalah khusus. Mereka mungkin sedang mengalami infeksi primer atau re-infeksi karena telah mendapatkan vaksinasi dan memiliki antibodi. Pengukuran kadar IgG rubella dengan ELISA juga dapat membantu membedakan infeksi primer dan re-infeksi.

Secara spesifik, ada 5 tujuan pemeriksaan serologis rubella, yaitu:

a. Membantu menetapkan diagnosis rubella kongenital. Dalam hal ini dilakukan imunoasai IgM terhadap rubella

b. Membantu menetapkan diagnosis rubella akut pada penderita yang dicurigai. Untuk itu perlu dilakukan imunoasai IgM terhadap penderita

c. Memeriksa ibu dengan anamnesis ruam "rubellaform" di masa lalu, sebelum dan pada awal kehamilan. Sebab ruam kulit semacam ini, dapat disebabkan oleh berbagai macam virus yang lain

d. Memantau ibu hamil yang dicurigai terinfeksi rubella selama kehamilan sebab seringkali ibu tersebut pada awal kehamilannya terpajan virus rubella (misalnya di BKIA dan Puskesmas)

e. Mengetahui derajat imunitas seseorang pascavaksinasi.

Adanya antibodi IgG rubella dalam serum penderita menunjukkan bahwa penderita tersebut pernah terinfeksi virus dan mungkin memiliki kekebalan terhadap virus rubella. Penafsiran hasil IgM dan IgG ELISA untuk rubella sebagai uji saring untuk 
kehamilan adalah sebagai berikut: sebelum kehamilan, bila positif ada perlindungan (proteksi) dan bila negatif berarti tidak diberikan, kehamilan muda (trimester pertama).

Kadar IgG $\geq 15 \mathrm{IU} / \mathrm{ml}$, umumnya dianggap dapat melindungi janin terhadap rubella. Setelah vaksinasi; bila positif berarti ada perlindungan dan bila negatif berarti tidak ada.

Tabel 2. Penafsiran hasil IgM dan IgG ELISA untuk rubella

\begin{tabular}{|l|l|l|}
\hline IgM & IgG & Penafsiran \\
\hline- & - & Tak ada perlindungan; perlu dipantau lebih lanjut \\
\hline+ & $\leq 15 \mathrm{IU} / \mathrm{ml}$ & Infeksi akut dini $(<1 \mathrm{minggu})$ \\
\hline+ & $\geq 15 \mathrm{IU} / \mathrm{ml}$ & $\begin{array}{l}\text { Baru mengalami infeksi } \\
(1-12 \text { minggu })\end{array}$ \\
\hline- & + & Imun, tidak perlu pemantauan lebih lanjut \\
\hline
\end{tabular}

3. Pemeriksaan RNA virus

Jenis pemeriksaan yang bisa dilakukan untuk mengenali RNA virus rubella antara lain:

a. Polymerase Chain Reaction (PCR): PCR merupakan teknik yang paling umum digunakan untuk menemukan RNA virus. Di Inggris, PCR digunakan sebagai metode evaluasi rutin untuk menemukan virus rubella dalam spesimen klinis. Penemuan RNA rubella dalam cairan amnion menggunakan RT-PCR mempunyai sensitivitas $87-100 \%$. Amniosintesis seharusnya dilakukan kurang dari 8 minggu setelah onset infeksi dan setelah 15 minggu konsepsi. Uji RT-PCR menggunakan sampel air liur merupakan alternatif pengganti serum yang sering digunakan untuk kepentingan pengawasan (surveillance).

b. Reverse Transcription-Loop-Mediated Isothermal Amplification (RT-LAMP) RTLAMP adalah salah satu jenis pemeriksaan untuk mengenali RNA virus rubella. Dalam sebuah penelitian yang membandingkan sensitivitas antara pemeriksaan RT-LAMP, RT-PCR dan isolasi virus yang dilakukan di Jepang, ternyata didapatkan hasil 77,8\% untuk RT-LAMP, 66,7\% untuk RT-PCR dan 33,3\% untuk isolasi virus. Pemeriksaan RT-LAMP mirip dengan pemeriksaan RT-PCR tetapi hasil pemeriksaan di RT-LAMP dapat diketahui dengan melihat tingkat kekeruhan (turbidity) setelah dilakukan inkubasi di alat turbidimeter.

\section{Diagnosa Banding}

Diagnosa banding yang perlu dipikirkan untuk rubella congenital antara lain adalah: ${ }^{7}$ 
1. Toksoplasmosis

2. Infeksi Cytomegalovirus

3. Infeksi virus Herpes Simplek

\section{Tabel.3 Manifestasi klinis dari infeksi kongenital}

\begin{tabular}{|c|c|c|c|c|}
\hline Sign & Cytomegalovins & Toxoplasmu & Rubella & Herpes Simplex Virus \\
\hline Hepatosplenomegaly & $+t$ & + & + & + \\
\hline Jaundice & + & + & + & + \\
\hline Exanthem & - & + & - & ++ \\
\hline Petechixe/purpura & t+ & + & + & - \\
\hline Hydrocephalus & + & ++ & - & + \\
\hline Microcephalus & $+t$ & + & - & + \\
\hline Intracerebral calcifications & t+ & ++ & - & + \\
\hline Heart defects & - & - & $+t$ & - \\
\hline Bone lesions & - & - & ++ & - \\
\hline Glavcoma & - & - & + & - \\
\hline Intrauterine growth restriction & + & + & + & + \\
\hline Chorioretinits & t+ & ++ & - & + \\
\hline Cataracts & - & - & ++ & + \\
\hline Adenopathy & - & + & + & + \\
\hline Dental defects & + & - & - & - \\
\hline
\end{tabular}

\section{Penatalaksanaan}

\section{Pengobatan}

Tidak ada pengobatan yang spesifik untuk CRS, pengobatannya hanya bersifat suportif.

a. Jika tidak terjadi komplikasi bakteri, pengobatan adalah simptomatis. Adamantanamin hidroklorida (amantadin) telah dilaporkan efektif in vitro dalam menghambat stadium awal infeksi rubella pada sel yang dibiakkan.

b. Upaya untuk mengobati anak yang sedang menderita CRS dengan obat ini tidak berhasil. Karena amantadin tidak dianjurkan pada wanita hamil, penggunaannya amat terbatas. Interferon dan isoprinosin telah digunakan dengan hasil yang terbatas.

c. Pada Bayi yang dilakukan tergantung kepada organ yang terkena:

-Gangguan pendengaran diatasi dengan pemakaian alat bantu dengar, terapi wicara dan memasukkan anak ke sekolah khusus atau implantasi koklea

-Penyakit jantung bawaan diatasi dengan pembedahan

-Gangguan penglihatan sebaiknya diobati agar penglihatan anak berada pada ketajaman yang terbaik seperti operasi

-keterbelakangan mentalnya diatasi dengan fisioterapi, terapi wicara, okupasi atau jika sangat berat, mungkin anak perlu dimasukkan ke institusi khusus. ${ }^{1}$

1. Cara Mencegah Rubella Pada Kehamilan

Vaksinasi sejak kecil atau sebelum hamil. Untuk perlindungan terhadap serangan virus Rubella telah tersedia vaksin dalam bentuk vaksin kombinasi yang sekaligus digunakan untuk mencegah infeksi campak dan gondongan, dikenal sebagai vaksin MMR (Mumps, Measles, 
Rubella). Vaksin Rubella diberikan pada usia 15 bulan. Setelah itu harus mendapat ulangan pada umur 4-6 tahun. Bila belum mendapat ulangan pada umur 4-6 tahun, harus tetap diberikan umur 11-12 tahun, bahkan sampai remaja. Vaksin tidak dapat diberikan pada ibu yang sudah hamil. ${ }^{9}$

1. Deteksi status kekebalan tubuh sebelum hamil. Sebelum hamil sebaiknya memeriksa kekebalan tubuh terhadap Rubella, seperti juga terhadap infeksi TORCH lainnya.

2. Jika anti-Rubella IgG saja yang positif, berarti Anda pernah terinfeksi atau sudah divaksinasi terhadap Rubella. Anda tidak mungkin terkena Rubella lagi.

3. Jika anti-Rubella IgM saja yang positif atau anti-Rubella IgM dan anti-Rubella IgG positif, berarti anda baru terinfeksi Rubella atau baru divaksinasi terhadap Rubella. Dokter akan menyarankan Anda untuk menunda kehamilan sampai IgM menjadi negatif, yaitu selama 3-6 bulan.

4. Jika anti-Rubella IgG dan anti-Rubella IgM negatif berarti anda tidak mempunyai kekebalan terhadap Rubella. Bila anda belum hamil, dokter akan memberikan vaksin Rubella dan menunda kehamilan selama 3-6 bulan. Bila anda tidak bisa mendapat vaksin, tidak mau menunda kehamilan atau sudah hamil, yang dapat dikerjakan adalah mencegah anda terkena Rubella.

5. Bila ibu sedang hamil mengalami demam disertai bintik-bintik merah, pastikan apakah benar Rubella dengan memeriksa IgG dan IgM Rubella setelah 1 minggu. Bila IgM positif, berarti benar infeksi Rubella baru.

6. Bila ibu hamil mengalami Rubella, pastikan apakah janin tertular atau tidak.

7. Untuk memastikan apakah janin terinfeksi atau tidak maka dilakukan pendeteksian virus Rubella dengan teknik PCR. Bahan pemeriksaan diambil dari air ketuban (cairan amnion). Pengambilan sampel air ketuban harus dilakukan oleh dokter ahli kandungan \& kebidanan, dan baru dapat dilakukan setelah usia kehamilan lebih dari 22 minggu.

8. Bagi wanita usia subur bisa menjalani pemeriksaan serologi untuk Rubella. Vaksinasi sebaiknya tidak diberikan ketika si ibu sedang hamil atau kepada orang yang mengalami gangguan sistem kekebalan akibat kanker, terapi kortikosteroid maupun penyinaran. Jika tidak memiliki antibodi, diberikan imunisasi dan baru boleh hamil 3 bulan kemudian.

\section{Prognosis}

Prognosis dari rubella postnatal baik dengan sembuh sempurna sedangkan congenital rubella syndrome prognosisnya buruk dengan disertai kerusakan organ multiple yang berat. $^{2}$ 


\section{Daftar Pustaka}

1. IDAI, 2016. Handryastuti,S, Sindrom Rubela Kongenital, Diakses 4 Juni 2018, Avaible from http://www.idai.or.id/artikel/klinik/keluhan-anak/sindrom-rubelakongenital

2. Ezike E, Steele RW, 2013. Pediatric Rubella, diakses 4 Juni 2018. Available from URL: http://emedicine.medscape.com/article/968523.

3. Kadek, Darmadi S, 2007. Gejala Rubela Kongenital (Kongenital) berdasarkan Pemeriksaan Serologis dan RNA Virus. Indonesian Journal of Clinical Pathology and Medical Laboratory :13(2):63-71.

4. Sugishita Y, Akiba T, Sumitomo M, Hayata N, Hasegawa M, Tsunoda T, Okazaki T, Murauchi K, Hayashi Y, Kai A, Seki N, Kayebeta A, Iwashita Y, Kurita M, Tahara N, 2015. Shedding of rubella virus in congenital rubella syndrome: study of affected infants born in Tokyo, Japan, 2013-2014. Japanese Journal of Infectious Diseases.

5. Giambi C, Filia A, Rota MC, Manso MD, Declich S, Naccal G, Rizzuto E, Bella A, 2014. Congenital rubella still a public health problem in Italy: analysis of national surveillance data from 2005 to 2013. Surveillance and Outbreak Reports.

6. Nguyen TV, Pham VH, Abe K, 2015. Pathogenesis of congenital rubella virus infection in human fetuses: viral infection in the ciliary body could play an important role in cataractogenesis. EbioMedicine, 2: 59-63.

7. McLean H, Redd S, Abernathy E, Icenogle J, Wallace G,2012. Chapter 15: Congenital Rubella Syndrome. In: VPD Surveillance Manual.Ed 5th

8. Lin C, Shih S, Tsai P, Liang A,2015. Is birth cohort 1985/9-1990/8 a suspceptibility window for congenital rubella syndrome in Taiwan?. Taiwanese journal of Obstetrics \& Gynecology.

9. Tian C, Ali SA and Weitkamp JH, 2010. Congenital Infections, Part I: Cytomegalovirus, Rubella and Herpes simplex. Neoroviews 11(8):e436-45.

10. Quintana EM, Solórzano CC, Torner N, González FR, 2015. Congenital rubella syndrome: a matter of concern. Pan American Journal of Public Health, 37 (3): 179186. 